\title{
Uniformity of the nuclear and chloroplast genomes of Spartina maritima (Poaceae), a salt-marsh species in decline along the Western European Coast
}

\author{
G Yannic ${ }^{1}$, A Baumel ${ }^{2}$ and $M$ Ainouche ${ }^{3}$ \\ ${ }^{1}$ Département d'Ecologie et d'Evolution, Bâtiment de Biologie, Université de Lausanne, CH-1015 Lausanne-Dorigny, Switzerland; \\ 'Institut Méditerranéen d'Ecologie et de Paléoécologie, University of Aix-Marseille III. Bâtiment Villemin, Europole de l'Arbois, BP 80, \\ 13545 Aix-en-Provence, Cedex 04, France; ${ }^{3}$ Speciation and Genome Evolution Lab., Department of Evolutionary Ecology, UMR CNRS \\ 6553, University of Rennes 1. Campus Scientifique de Beaulieu, 35042 Rennes, Cedex, France
}

\begin{abstract}
Spartina maritima is a salt-marsh species from European and African Atlantic coasts. In the northern range of the species (including north-west France), a rapid decline of the populations has been observed during the 20th century. In this paper, the molecular diversity of 10 populations of S. maritima from France has been investigated using nuclear and chloroplast DNA markers: inter-simple sequence polymorphism (ISSR), randomly amplified polymorphic DNA (RAPD), inter-retrotransposon amplified polymorphism (IRAP), and PCR-RFLP of a $5 \mathrm{~kb}$ long portion of chloroplast DNA. The results reveal an extremely low level of genetic
\end{abstract}

variation in this species: only one nuclear marker (out of 98) was polymorphic, with the presence of two genotypes randomly distributed among the populations. The lack of genetic diversity is interpreted in light of the almost exclusive vegetative propagation of the species in its northern range, the colonization history of the populations, and the origin of $S$. maritima $(2 n=60)$ in the hexaploid lineage of the genus and in the context of the management of $S$. maritima populations.

Heredity (2004) 93, 182-188, advance online publication, 2 June 2004; doi:10.1038/sj.hdy.6800491

Keywords: Spartina; clonal plant; RAPD; ISSR; IRAP; genetic uniformity

\section{Introduction}

The salt-marsh grass, Spartina maritima Curtis (Poaceae) covers a wide and discontinuous range from South Africa to North Europe along the Atlantic seaboard (Mobberley, 1956). Until the 19th century it was the only Spartina species known on the Atlantic European coast (Marchant and Goodman, 1969). This native species has an important role as primary colonist of intertidal mud flats since it is able to trap and stabilize sediment efficiently, thus facilitating successional development (Castillo et al, 2000). In the beginning of the 19th century, S. alterniflora Loisel was introduced from the Northeast American coast by ship's ballast into Southampton water (Southern England) and the Bidassoa estuary (Southwest France). Hybridization with local $S$. maritima plants gave rise to sterile hybrids, named Spartina $\times$ townsendii and Spartina $\times$ neyrautii, in England and in France, respectively (Groves and Groves, 1881; Foucaud, 1897). Around 1890, a chromosome doubling in $S . \times$ townsendii resulted in a fertile allopolyploid species, $S$. anglica, in Southampton water (Hubbard, 1968; Gray et al, 1990). Both F1 hybrids

Correspondence: M Ainouche, Speciation and Genome Evolution Lab., Department of Evolutionary Ecology, UMR CNRS 6553, University of Rennes 1. Campus Scientifique de Beaulieu, 35042 Rennes, Cedex, France. E-mail: Malika.Ainouche@univ-rennes1.fr

Received 21 March 2003; accepted 31 March 2004; published online 2 June 2004 are exclusively clonal species that remain localized in the site of hybridization, whereas S. anglica is a particularly vigorous and invasive species, which has spread both naturally and as a result of artificial plantations to become a particularly invasive species on different continents (Thompson, 1991; Guénégou and Levasseur, 1993; Gray and Raybould, 1997). Recent molecular investigations have revealed that this species displays a remarkable lack of interindividual genotypic variation (Baumel et al, 2001, 2002b; Ainouche et al, 2004a).

Spartina anglica was first recorded in France in 1906 and since then, it has rapidly spread all along the French coast. At the same time, the regression of $S$. maritima has been observed in British and northwest (Brittany) French salt marshes (Marchant, 1967; Raybould et al, 1991b; Guénégou and Levasseur, 1992). In Southampton water for example, all $S$. maritima plants have now disappeared (Raybould et al, 2000). Marchant (1967) and Des Abbayes et al (1971) suggested that the regression of S. maritima in northern Europe has been accelerated by $S$. anglica invasion that had supplanted $S$. maritima populations. However, it has also been noticed that the decay of S. maritima populations is also observed in sites where S. anglica is not present, and that the allopolyploid colonizes open bare flats rather than previously extant vegetation areas (Raybould et al, 1991b). Therefore, these two species may not really be competitors, and may differ in their strategy of dissemination (Baumel et al, 2001). 
North European populations of S. maritima lack vigor; they are characterized by slow lateral extension of individuals that rarely reproduce sexually, while southern European and African plants are bigger, more robust and produce viable seeds (Marchant, 1967). The variation in vigor may result from more stressful environmental conditions encountered by plants introduced from Africa in Northern areas of Europe (Chevalier, 1923; Marchant, 1967). Moreover, S. maritima is usually a dominant species of the lower marsh in numerous coastal marshes and estuaries. This habitat is particularly vulnerable to global warming. Actually, a consequence of the enhanced greenhouse effect is the rise of the sea level (Titus et al, 1991). An average sea-level rise is predicted to be about $20 \mathrm{~cm}$ by 2050 (IPCC, 2001), and Van Wijnen and Bakker (2001) predicted that marshes at lowest elevation would degenerate. Consequently, it can be expected that the sea-level rise will erode the outer boundary of the salt marshes, that is the lower marsh habitat of Spartina species. In England, Raybould et al (1991b) noticed in 1986 that the few remaining populations of $S$. maritima were frequently confined to eroded, high level marshes with dense vegetation. Therefore, the severe decline of the populations should be considered a sign of a threat in the northern range of the species in Europe. Several recent publications pinpoint the importance of genetic diversity ('neutral' and 'adaptive') for population level responses to environmental change (for a review, see Fraser and Bernatchez, 2001; Hedrick, 2001). Molecular markers provide appropriate tools for the definition of conservation units based on genetic diversity and allow for the evaluation of levels of genetic variability in relation to the vegetative extent of natural populations. For a plant reproducing mainly by vegetative growth, like $S$. maritima, what appears to be a 'large' population may be actually 'small' in terms of effective population size. For conservation purposes, it is therefore of interest to estimate the levels of genetic variation in populations of $S$. maritima growing on the northern limit of the species where they have been regressing for more than a century. To our knowledge, no molecular diversity analysis has been performed to date at the DNA level in S. maritima populations. A previous study based on allozyme markers revealed a lack of genetic variation in British populations (Raybould et al, 1991b). For these reasons, the objective of the present study is to evaluate the amount and distribution of genetic variation within and between populations of $S$. maritima along the French
Atlantic coast where both healthy and regressing populations occur.

\section{Materials and methods}

\section{Population sampling}

A total of $10 \mathrm{~S}$. maritima populations were sampled during spring 2001 from Saint-Briac (Côtes d'Armor, France) to Seudre estuary (Charente Maritime, France) on the Channel and Atlantic French coast, respectively (Table 1). From 3 to 20 individuals per population were collected, forming 125 samples for analysis. Vegetative characters were used in the field to distinguish the two species. Compared to $S$. maritima, the leaves of $S$. anglica are wider, straighter, and form a broad angle with the culm, whereas the leaves of $S$. maritima form an acute angle with the culm and are readily disarticulated from the sheath (Mobberley, 1956). In Saint Briac, Saint-Armel, and Seudre, S. maritima grows in sympatry with $S$. anglica. In Saint Armel particularly, patches consist of mixed clones of both species. The corresponding sampled populations were then used to check for possible gene flow between the two species (see data analysis).

Individual plants were collected in the field with roots, leaves, and rhizomes to allow both DNA extraction (from leaves) and transplantation into the greenhouse. As Spartina species are clonal plants, at each site, we tried to maximize the distance between samples to avoid collecting from the same individual (minimum distance: $50 \mathrm{~m}$ in large populations and $3 \mathrm{~m}$ in small populations composed of scattered clones).

\section{Molecular methods}

Three PCR-based fingerprinting techniques have been used: random amplified polymorphic DNA (RAPD, Williams et al, 1990); inter-simple sequence repeats (ISSR, Wolfe et al, 1998); and inter-retrotransposon amplified polymorphism (IRAP, Kalendar et al, 1999). In addition, the PCR-RFLP approach was developed to detect chloroplast diversity among $S$. maritima populations.

\section{DNA extraction}

DNA was prepared by the cetyltrimethylammonium bromide (CTAB) method (Ausubel et al, 1995) with RNaseA treatment. Approximately $30 \mathrm{mg}$ of fresh leaves were ground in a $2 \%$ CTAB solution $(1.4 \mathrm{M} \mathrm{NaCl}, 20 \mathrm{mM}$ EDTA, $100 \mathrm{mM}$ Tris $\mathrm{HCl} \mathrm{pH} 8.0,2 \%$ CTAB). The extract

Table 1 List of sampled sites

\begin{tabular}{|c|c|c|c|c|}
\hline Sites & No. & Location & Population feature & Number of Samples \\
\hline Saint Briac & 1 & Côtes d'Armor & $\begin{array}{l}\text { Scattered patches in the Frémur estuary, in sympatry } \\
\text { with S. anglica }\end{array}$ & 9 \\
\hline Ile Chevalier & 2 & Finistère & Large and continuous meadow & 20 \\
\hline Laïta & 3 & Finistère & Small population along the Laita river & 10 \\
\hline Plouharnel & 4 & Morbihan & Large and continuous meadow & 10 \\
\hline Auray & 5 & Morbihan & Large and continuous meadow & 20 \\
\hline Saint Armel & 6 & Morbihan & Large population with mixed patches with $S$. anglica & 19 \\
\hline Pen Bron & 7 & Loire-Atlantique & Large population & 10 \\
\hline Port du Pavé & 8 & Vendée & One isolated patch in a harbor zone & 3 \\
\hline Noirmoutier & 9 & Vendée & Large and continuous meadow & 15 \\
\hline Seudre & 10 & Charente-Maritime & $\begin{array}{l}\text { Small population formed of scattered patches along } \\
\text { the Seudre river, in sympatry with S. anglica }\end{array}$ & 9 \\
\hline
\end{tabular}


was incubated for $1 \mathrm{~h}$ at $65^{\circ} \mathrm{C}$, and then $500 \mu \mathrm{l}$ of chloroform was added. After mixing and microcentrofugation, $500 \mu \mathrm{l}$ of isopropanol was added to the supernatant for precipitation. After microcentrofugation, the genomic DNA pellet was washed with $70 \%$ ethyl alcohol, and then it was resuspended in Tris-EDTA buffer.

\section{RAPD procedure}

Based on the use of a single short arbitrarily designed primer, RAPDs (Williams et al, 1990) are now commonly used for estimating genetic variation at the intraspecific level. Genomic DNA was amplified using five 10-mer random oligonucleotide primers (Operon Technologies): Op-C2, Op-C5, Op-C9, Op-C10, and Op-C20. These primers have been selected from among a set that released clear and reproducible electrophoresis patterns in a previous study on Spartina (Baumel et al, 2001).

Each PCR volume of $20 \mu \mathrm{l}$ for RAPD contained $40 \mathrm{ng}$ of genomic DNA, $1 \times$ incubation Taq Buffer (Sigma), $1.1 \mathrm{mM}$ of $\mathrm{MgCl}_{2}, 0.2 \mathrm{mM} \mathrm{dNTP}, 0.2 \mu \mathrm{M}$ Operon primer, and $1.25 \mathrm{U}$ of red Taq polymerase (Sigma). Amplification reactions were performed in a Techne thermal cycler programmed as follows: $1 \mathrm{~min}$ at $94^{\circ} \mathrm{C}$ followed by 45 cycles of $1 \mathrm{~min}$ at $94^{\circ} \mathrm{C}, 1 \mathrm{~min}$ at $36^{\circ} \mathrm{C}$, and $2 \mathrm{~min}$ at $72^{\circ} \mathrm{C}$. An additional cycle of $15 \mathrm{~min}$ at $72^{\circ} \mathrm{C}$ was used for final extension. Negative controls without DNA template were run with each experiment.

\section{ISSR procedure}

ISSRs represent sequences bracketed by microsatellite (SSRs) sites situated on two opposite DNA strands (Gupta et al, 1994). They are amplified by PCR using a single-primer designed from a di- or trinucleotide repeat with a random anchoring sequence of one to three nucleotides. ISSRs have been shown to be useful for molecular fingerprinting in natural populations (Wolfe et al, 1998; Esselman et al, 1999) or even to display somaclonal variation (Leroy et al, 2000). In this study, the following SSR primers were used: $(\mathrm{AGC})_{6} \mathrm{C},(\mathrm{TGC})_{6} \mathrm{G}$, $(\mathrm{GTG})_{7} \mathrm{C},(\mathrm{CTC})_{6} \mathrm{G}$, and $(\mathrm{CT})_{9} \mathrm{G}$.

Amplifications for the ISSR procedure were conducted as following: Each PCR volume of $20 \mu \mathrm{l}$ contains $1 \times$ incubation Taq Buffer (Sigma), $1.1 \mathrm{mM} \mathrm{MgCl}_{2}, 0.2 \mathrm{mM}$ dNTPs, $0.2 \mu \mathrm{M}$ each primer, $1 \mathrm{U}$ of red Taq polymerase (Sigma), and $40 \mathrm{ng}$ DNA template. Amplifications were performed in a PCR-express (Hybaid) thermal cycler using the following program: $2 \mathrm{~min}$ at $94^{\circ} \mathrm{C}$ followed by 35 cycles of $45 \mathrm{~s}$ at $94^{\circ} \mathrm{C}, 45 \mathrm{~s}$ at $52^{\circ} \mathrm{C}$ for $(\mathrm{CT})_{9} \mathrm{G}$ or $58^{\circ} \mathrm{C}$ for the other primers, $2 \mathrm{~min}$ at $72^{\circ} \mathrm{C}$, and terminated by $10 \mathrm{~min}$ of final extension at $72^{\circ} \mathrm{C}$. Negative controls without DNA template were also run with each experiment.

\section{IRAP procedure}

The IRAP provides PCR-based markers depending on the position of given long terminal repeats (LTRs) of retrotransposons within the genome. The IRAP markers are generated by the proximity of two LTRs, using outward-facing primers annealing to LTR target sequences (Kalendar et al, 1999). The characteristics of retrotransposons (high mutation rate, dispersion over the whole genome, insertion and recombination) and the wide distribution of their activity in the plant kingdom make them particularly suitable for fingerprinting
(Kalendar et al, 1999). This technique allows detecting the insertion polymorphism of retroelements in the genome. IRAP has been previously used in population genetics in the genus Hordeum (Kalendar et al, 1999) and later, successfully adapted to the genus Spartina (Baumel et $a l, 2002 \mathrm{~b})$. Interretrotransposon fragments were generated using the 'BAGGY' LTR primer (TCG TCG CCG GCG TCA TCT CC), kindly provided by R Kalendar and A Schulman (Plant genomics laboratory, University of Helsinki). PCR conditions for IRAP were similar to those of ISSR, except that a $59^{\circ} \mathrm{C}$ annealing temperature was used.

\section{Electrophoresis procedures for ISSR, RAPD, and IRAP}

After PCR amplification, products were stored at $4{ }^{\circ} \mathrm{C}$ until electrophoresis. Amplified products were electrophoresed in $1.5 \%$ agarose gels in $0.5 \times$ TBE buffer. Gels were stained in a $5 \%$ ethidium bromide solution for $30 \mathrm{~min}$, then washed in water for $10 \mathrm{~min}$ and photographed under UV light.

Analysis of the rbcL-retA region by $\mathrm{PCR}$-RFLP procedure A chloroplast DNA region of $5 \mathrm{~kb}$ flanked by the $r b c L$ and the $\operatorname{ret} A$ genes was amplified. This region contains approximately $2500 \mathrm{bp}$ of noncoding DNA. Sequences of the primers $(r b c L$ ATG TCA CCA CAA ACA GAG ACT AAA GCA AGT; retA: CCG GCC GGT AGC TTC TCG AGG ATT TTC) were kindly provided by $\mathrm{K}$ Schierenbeck (California Sate University, Chico, CA, USA). RFLP was examined by using nine restriction enzymes (AluI, Bsh1236I, EcoRV, HaeIII, Hin6I, HinfI, MboI, MspI, RsaI) on 10 individuals representing the 10 populations of S. maritima (Table 1).

Each PCR volume of $100 \mu$ l contained $40 \mathrm{ng}$ of genomic DNA, $10 \mu \mathrm{l}$ of incubation buffer (Sigma), $1.1 \mathrm{mM} \mathrm{MgCl}$, $2 \mathrm{mM} \mathrm{dNTP}, 50 \mu \mathrm{M}$ each primer, and $5 \mathrm{U}$ of red Taq polymerase (Sigma). Reactions were placed in a Techne thermal cycler programmed as follows: $4 \mathrm{~min}$ at $94^{\circ} \mathrm{C}$ followed by 28 cycles of $45 \mathrm{~s}$ at $94^{\circ} \mathrm{C}, 1 \mathrm{~min}$ and $15 \mathrm{~s}$ at $52^{\circ} \mathrm{C}$, and $9 \mathrm{~min}$ and $30 \mathrm{~s}$ at $65^{\circ} \mathrm{C}$. Negative controls without DNA template were run with each experiment.

Restriction reactions $(20 \mu \mathrm{l})$ contained $1 \times$ incubation buffer, $10 \mu \mathrm{l}$ of PCR product, and $5 \mathrm{U}$ restriction enzyme. After $3 \mathrm{~h}$ at $37^{\circ} \mathrm{C}$, restriction reactions were run on $2 \%$ agarose gels in TBE buffer and fragments were visualized following ethidium bromide staining.

\section{Data analysis}

Repeatability of the banding patterns and polymorphism were tested for each primer. Ambiguous and nonreproducible bands were not included in the analysis.

Molecular variation in S. maritima was analyzed by scoring polymorphic bands in the presence/absence of data matrix. Potential hybrid genotypes between S. maritima and S. anglica were looked for in mixed populations by comparing the obtained phenotypes to previously identified genotypes of $S$. anglica (Baumel et al, 2001, 2002a; A Baumel unpublished data).

\section{Results}

The five RAPD primers generated 50 repeatable markers in S. maritima. No polymorphism was encountered for any fragments among the 125 samples analyzed. 


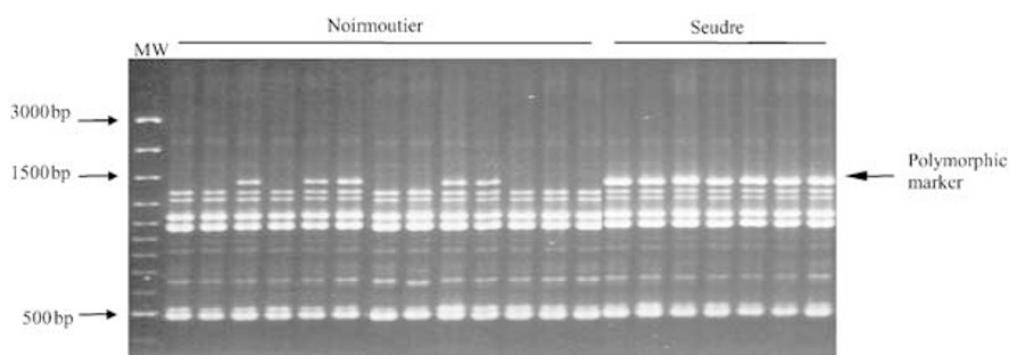

Figure 1 ISSR banding patterns obtained with (TGC) 6 G primer. Lane 1, DNA ladder, lanes 2-11, S. maritima population from Noirmoutier. The arrow on the right indicates the polymorphic band.

Table 2 Frequency of the two genotypes encountered in S. maritima. Genotype no. 1: absence of the $1450 \mathrm{bp}$ (TGC) 6 G band. Genotype no. 2: presence of the $1450 \mathrm{bp}$ (TGC) 6 G band

\begin{tabular}{lrcc}
\hline Sites & $N$ & Genotype no. 1 & Genotype no. 2 \\
\hline Saint Briac & 9 & 9 & 0 \\
Ile Chevalier & 20 & 2 & 18 \\
Laïta & 10 & 10 & 0 \\
Plouharnel & 10 & 10 & 0 \\
Auray & 20 & 20 & 0 \\
Saint Armel & 19 & 13 & 6 \\
Pen Bron & 10 & 10 & 0 \\
Noirmoutier & 15 & 9 & 6 \\
Port du Pavé & 3 & 1 & 2 \\
Seudre & 9 & 0 & $91(33 \%)$ \\
Total & 125 & $84(67 \%)$ &
\end{tabular}

Therefore, all S. maritima samples share the same RAPD pattern. Similarly, the BAGGY LTR primer used for IRAP generated six repeatable and monomorphic markers. RFLP analysis of the plastid $r b c L-r e t A$ region yielded 68 invariant restriction sites, showing that all sampled individuals share the same cpDNA haplotype with respect to the restriction sites surveyed.

The only molecular variation observed was detected using ISSR analysis, and in this case, only one of 42 repeatable markers was polymorphic. The repeatability of this polymorphism generated by the (TGC) ${ }_{6} \mathrm{G}$ primer was confirmed by new DNA extractions and new PCRs. The presence or absence of this approximately $1450 \mathrm{bp}$ band (Figure 1) differentiates two genotypes. Genotype no. 1 lacks the band and represents $67 \%$ of the samples (Table 2), whereas the genotype 2 (which has the band) represents $33 \%$ of the samples. Five of 10 populations are composed exclusively of genotype no. 1; four populations have both genotypes, and only one population is fixed for genotype 2. The two genotypes are present throughout the area sampled and their distribution is not geographically structured (Figure 2).

In summary, our analysis of nuclear and chloroplast DNA variation reveals only two clones on the French coast, differing only by the presence/absence of one (ISSR) nuclear DNA fragment that is present in 33\% and absent in $67 \%$ of the 125 individuals analyzed.

\section{Discussion}

Our study reveals remarkable genetic uniformity in French populations of S. maritima. This uniformity was unexpected considering the physiognomy of the popula-

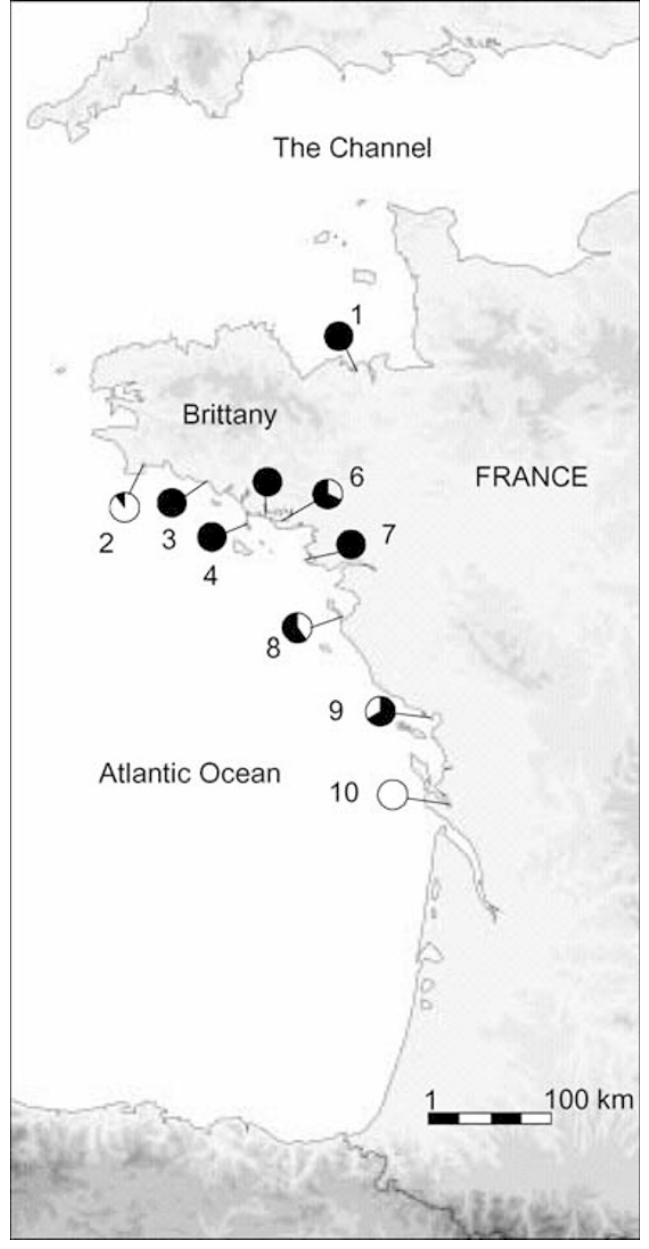

Figure 2 Geographic distribution of the two S. maritima genotypes encountered in the sampling area. - Genotype no. 1: absence of the $1450 \mathrm{bp}(\mathrm{TGC})_{6} \mathrm{G}$ band. $\bigcirc$ Genotype no. 2: presence of the $1450 \mathrm{bp}$ (TGC) 6 G band.

tions investigated, ranging from small populations with scattered plants to large populations forming extensive meadows. No chloroplast DNA diversity was detected and only two nuclear genotypes were encountered throughout the entire collecting area. These genotypes are very similar as they are differentiated by only one DNA fragment out of 98 amplified. Although based on different sample sets, similarly low levels of genetic diversity were also reported by Raybould et al (1991b) in English populations analyzed by isozyme markers. Their 
results show that $S$. maritima in the UK is mostly represented by one ubiquitous genotype, with rare variants for two enzyme systems. Thus, the level of genetic diversity detected in S. maritima with PCR-based DNA markers does not differ from that determined with isozymes. This situation is in sharp contrast with studies on other species, where allozymes often underestimate genetic diversity in populations and species and where additional variation has been detected as soon as other markers were employed (eg Piquot et al, 1996; Esselman et al, 1999).

The absence of cpDNA variation and the presence of only two very similar nuclear genotypes in French $S$. maritima populations can be interpreted in light of the historical biogeography and evolution of this species in the genus Spartina. The European coasts represent the northern limit of the distribution area of $S$. maritima, which extends from the UK to the Cape of Good Hope in South Africa (Mobberley, 1956). How did S. maritima occupy a wide and discontinuous range from South Africa to North Europe? This raises the question of the origin of S. maritima within the hexaploid lineage of the Spartina species (Baumel et al, 2002a). This lineage is composed of the Afro-European Atlantic S. maritima $(2 n=60)$, and the two sister species, the East American S. alterniflora $(2 n=62)$ and the West American $S$. foliosa $(2 n=60)$. These three species have nonoverlapping native distribution ranges but they maintain sufficient genetic relatedness to hybridize (Baumel et al, 2002a; Ainouche et al, 2004b). Since S. maritima is basal in this clade according to the phylogeny of genus Spartina (Baumel et al, 2002a), one can hypothesize that current populations of $S$. maritima actually represent a relic of an ancestral hexaploid species with a more widespread distribution. Another, less likely, possibility is that S. maritima was introduced from America to the eastern Atlantic coast and subsequently vanished from the New World.

On a shorter time scale, Chevalier (1923) suggested that the species is only native to South Africa and NW Africa from Mauritania to Morocco and from Gibraltar to the Loire estuary, and that it was introduced by shipping to more northern localities. Thus, a drastic founder effect is a possible explanation for the widespread genotypic uniformity. To examine this hypothesis, it would be interesting to evaluate the amount of genetic diversity throughout the distribution area of S. maritima. A preliminary analysis (G Yannic and A Baumel unpublished data) revealed that both genotypes (no. 1 and no. 2) are also observed in one sample from Portugal and Spain, respectively, and that genotype no. 1 is also present in Mauritania. These observations would suggest that both genotypes 1 and 2 were present in S. maritima prior to its progression along the French coast and were maintained through strict clonal spread. In the current state of our investigations, no other genotypes were scored in the southern range of the species, but the small sampling size in this area precludes any conclusion about the founder hypothesis.

A second related issue lies in the fact that $S$. martima rarely produces seeds in northern Europe. In French populations, we have observed normal flowering and fertile pollen but no seed production or seedling germination (Baumel, personal observation). Castellanos et al (1994) also reported the absence of germination in
Spanish populations of $S$. maritima. The marginal situation of the populations analyzed here is relevant to the lack of sexual reproduction, a common feature of populations at the geographic margins of a species range (Eckert, 2002). Although seed production and sexual recruitment may often be limited by biotic and abiotic environmental factors in marginal populations, genetic factors, including change in ploidy or mutation, may also play a role in causing reduced sexual fertility (Eckert, 2002). For example, Eckert et al (1999) show evidence for loss of sexual capacity in highly clonal populations of Decodon verticillatus, providing strong support to the hypothesis that complex traits like sex are degraded by mutation when they no longer increase fitness. Then, the genetic uniformity in $S$. maritima observed here could be explained by a complex interaction between ancient founder effects and more recent loss of sexual capacity. Both issues will be addressed in further analysis of the species on a broader range.

Comparison of S. maritima to its most related species, S. alterniflora (Baumel et al, 2002a), reveals that the population genetics of these two species is very different (Ainouche et al, 2004b). The East-American S. alterniflora has been introduced to the Pacific coast of the US where it is now an invasive weed, most notably in the San Francisco Bay area (Daehler and Strong, 1997) and in Willapa Bay (Aberle 1993 in Daehler and Strong, 1997). In both sites, as well as on the eastern coast, the species shows a high level of nuclear and chloroplast diversity (Stiller and Denton 1995; Anttila et al, 2000; Perkins et al, 2002).

Despite the low level of genetic variation revealed in the present study, our results have interesting implications considering the origins of the recent hybrid and allopolyploid Spartina species. Chloroplast DNA markers revealed that $S$. maritima is the paternal parent of the sterile hybrid $S$. $\times$ townsendii and the allopolyploid $S$. anglica (Ferris et al, 1997; Baumel et al, 2001). Populations of S. anglica are mainly composed of one 'major' multilocus genotype, resulting from strict additivity of the nuclear genomes from S. maritima and S. alterniflora (Baumel et al, 2001). The unique vs multiple origin of the allopolyploid has been questioned (Raybould et al, 1991a, b; Baumel et al, 2001; Ainouche et al, 2004a). The results of the present study show that if multiple hybridization events occurred, they would have involved the same $S$. maritima genotype, identified here as the S. maritima 'genotype 1 '. S. maritima and $S$. alterniflora have been involved in another hybridization event in Southern France (Foucaud, 1897), where the molecular characterization of the resulting sterile hybrid, $S$. $\times$ neyrautii (Baumel et al, 2003), indicates that $S$. maritima was the paternal genome donor (as for $S$. $\times$ townsendii and S. anglica, Ferris et al, 1997; Baumel et al, 2001). The genotype of S. maritima involved in the hybridization (in Spain) was 'genotype no. 2', as identified here.

As Raybould et al (1991b) argue, conservation of $S$. maritima may best be achieved by the protection of the larger populations. In the light of our results, it may be concluded that the French populations represent only one conservation unit. However, further surveys of phenotypic and quantitative genetic variation are needed for conservation purposes (Fraser and Bernatchez, 2001). Considering that $S$. maritima is exposed to marine erosion 
and that it is characterized by very low variation, it may be predicted that this species will be very sensitive to future changes affecting the littoral environment. Therefore, numerous populations living in different ecological situations should be preserved all along the geographical range of the species. Finally, this study demonstrates that any French population could be chosen as planting stock for restoration of salt marshes in northern Europe.

\section{Acknowledgements}

This work is funded by UMR CNRS 6553 Ecobio, University of Rennes 1. We are grateful to Randy Bayer (CSIRO, Canberra), Jonathan Wendel (Iowa State University, Ames), John D Thompson, CEFE (Montpellier) for helpful comments and $\mathrm{K}$ Schierenbeck for primer sequences.

\section{References}

Ainouche ML, Baumel A, Salmon A (2004a). Spartina anglica C.E. Hubbard: a natural model system for analysing early evolutionary changes that affect allopolyploid genomes. Biol J Linn Soc (in press).

Ainouche ML, Baumel A, Salmon A, Yannic G (2004b). Hybridization, polyploidy and speciation in Spartina Schreb. (Poaceae). New Phytol. 161: 165-172.

Anttila CK, King RA, Ferris C, Ayres DR, Strong DR (2000). Reciprocal hybrid formation of Spartina in San Francisco Bay. Mol Ecol 9: 765-770.

Ausubel FM, Brent R, Kingston RE, Moore DD, Seidman JG, Smith JA et al. (1995). Current Protocols in Molecular Biology. John Wiley and Sons: New York.

Baumel A, Ainouche ML, Bayer RJ, Ainouche AK, Misset MT (2002a). Molecular phylogeny of hybridizing species from the genus Spartina Schreb. (Poaceae). Mol Phylogenet Evol 22: 303-314.

Baumel A, Ainouche ML, Kalendar R, Schulman AH (2002b). Retrotransposons and genomic stability in populations of the young allopolyploid species Spartina anglica C.E. Hubbard (Poaceae). Mol Biol Evol 19: 1218-1227.

Baumel A, Ainouche ML, Levasseur JE (2001). Molecular investigations in populations of Spartina anglica C.E. Hubbard (Poaceae) invading coastal Brittany (France). Mol Ecol 10: $1689-1702$.

Baumel A, Ainouche ML, Misset MT, Gourret JP, Bayer RJ (2003). Genetic evidence for hybridization between the native Spartina maritima and the introduced Spartina alterniflora (Poaceae) in South-West France: Spartina $\times$ neyrautii reexamined. Plant Syst Evol 237: 87-97.

Castellanos EM, Figueroa ME, Davy AJ (1994). Nucleation and facilitation in saltmarsh succession: interactions between Spartina maritima and Arthrocnemun perenne. J Ecol 82: 239-248.

Castillo JM, Fernandez-Baco L, Castellanos EM, Luque CJ, Figueroa ME, Davy AJ (2000). Lower limits of Spartina densiflora et $S$. maritima in Mediterranean salt marsh determined by different ecophysiological tolerances. J Ecol 88: 801-812.

Chevalier A (1923). Note sur les Spartina de la flore française. $B$ Soc Bot Fr 70: 54-63.

Daehler CC, Strong DR (1997). Hybridization between introduced smooth cordgrass (Spartina alterniflora, Poaceae) and native California cordgrass (Spartina foliosa) in San Francisco Bay, California, USA. Am J Botany 84: 607-611.

Des Abbayes H, Claustres G, Orillion R, Dupont P (1971). Flore et Végétation du Massif Armoricain, Flore Vasculaire. Presse Universitaire De Bretagne: Saint Brieuc. Tome 1.
Eckert CG (2002). The loss of sex in clonal plants. Evol Ecol 15 501-520.

Eckert CG, Dorken ME, Mitchell SA (1999). Loss of sex in clonal populations of a flowering plant, Decodon verticillatus (Lythraceae). Evolution 53: 1079-1092.

Esselmann EJ, Jianqiang L, Crawford DJ, Windus JL, Wolfe AD (1999). Clonal diversity in the rare Calamagrostis porteri spp. insperata (Poaceae): comparative results for allozymes and random amplified polymorphic DNA (RAPD) and intersimple sequence repeat (ISSR) markers. Mol Ecol 8: 443-451.

Ferris C, King RA, Gray AJ (1997). Molecular evidence for the maternal parentage in the hybrid origin of Spartina anglica C.E.Hubbard. Mol Ecol 6: 185-187.

Foucaud J (1897). Un Spartina inédit. Ann Soc Sci Nat CharenteInf 32: 220-222.

Fraser D, Bernatchez L (2001). Adaptive evolutionary conservation: toward a unified concept for defining conservation units. Mol Ecol 10: 2741-2752.

Gray AJ, Benham PEM, Raybould AF (1990). Spartina anglica The evolutionary and ecological background. In: Gray AJ, Benham PEM (eds) Spartina anglica - a Research Review. NERC: HMSO, London, pp 5-10.

Gray AJ, Raybould AF (1997). The history and evolution of Spartina anglica in the British Isles. In: Patten K (ed) Proceedings of the Second International Spartina Conference. Washington State University, Cooperative Extension, Olympia, pp 13-16.

Groves H, Groves J (1881). Spartina townsendii H. and J. Groves. Rep Bot, Soc Exch Club Br Isl 8: 37.

Guénégou MC, Levasseur JE (1992). Le genre Spartina en Bretagne. B Soc Bot Centre Ouest 23: 35-38.

Guénégou MC, Levasseur JE (1993). La nouvelle espèce amhiploïde Spartina anglica C.E. Hubbard: son origine, argumentation et implications. Biogeographica 69: 125-133.

Gupta M, Chyi YS, Romero-Severson J, Owen JL (1994). Amplification of DNA markers from evolutionary diverse genomes using single primers of simple-sequence repetas. Theor Appl Genet 89: 998-1006.

Hedrick PW (2001). Conservation genetics: where are we now? Trends Ecol Evol 16: 629-636.

Hubbard CE (1968). Grasses 2nd edn Penguin Books: London.

Intergovernmental Panel on climate change (IPCC) (2001). Climate Change (2001): The Scientific Basis. Summary for Policymakers (SPM) and Technical Summary (TS). IPCC: Geneva, Switzerland. http://www.ipcc.ch/pub/reports.htm.

Kalendar R, Grob T, Regina M, Suoniemi A, Schulman AH (1999). IRAP and REMAP: two new retrotransposonbased DNA fingerprinting techniques. Theor Appl Genet 98: 704-711.

Leroy XJ, Leon K, Branchard M (2000). Plant genomic instability detected by microsatellite-primers. Electron J Biotechnol 3 140-148.

Marchant CJ (1967). Evolution in Spartina (Gramineae). I. History and morphology of the genus in Britain. J Linn Soc 60: 1-24.

Marchant CJ, Goodman PJ (1969). Spartina maritima (Curtis) Fernald. J Ecol 57: 287-291.

Mobberley DG (1956). Taxonomy and distribution of the genus Spartina. Iowa State College J Sci 30: 471-574.

Perkins EJ, Streever WJ, Davis E, Fredrikson HL (2002). Development of amplified fragment length polymorphism markers for Spartina alterniflora. Aquat Bot 74: 85-95.

Piquot Y, Saumitou-Laprade P, Petit D, Vernet P, Epplen JT (1996). Genotypic diversity revealed by allozymes and oligonucleotide DNA fingerprinting in French populations of the aquatic macrophyte Sparganium erectum. Mol Ecol 5: 251-258.

Raybould AF, Gray AJ, Hornby DD (2000). Evolution and current status of the salt marshes grass, Spartina anglica, in 
the Solent. In: Collins M, Ansell K (eds) Solent Science - $a$ Review. Elsevier Science: Amsterdam.

Raybould AF, Gray AJ, Lawrence MJ, Marshall DF (1991a). The evolution of Spartina anglica C.E. Hubbard (Gramineae): origin and genetic variability. Biol J Linn Soc 43: 111-126.

Raybould AF, Gray AJ, Lawrence MJ, Marshall DF (1991b). The evolution of Spartina anglica C.E. Hubbard (Gramineae): genetic variation and status of the parental species in Britain. Biol J Linn Soc 44: 369-380.

Stiller JW, Denton AL (1995). 100 years of Spartina alterniflora (Poaceae) in Willapa Bay, Washington - random amplified polymorphic DNA analysis of an invasive population. Mol Ecol 4: 355-363.

Thompson JD (1991). The biology of an invasive plant. What makes Spartina anglica so successful? Bioscience 41: 393-401.
Titus JG, Park RA, Leatherman SP, Weggel JR, Greene MS, Mausel PW et al (1991). Greenhouse effect and sea level rise: the cost of holding back the sea. Coast Manage 18: 171-204.

Van Wijnen HJ, Bakker JP (2001). Long-term surface elevation change in salt marshes: a prediction of marsh response to future sea-level rise. Estuar Coast Shelf Sci 52: 381-390.

Williams JGK, Kubelik AR, Livak KJ, Rafalski JA, Tingey SV (1990). DNA polymorphisms amplified by arbitrary primers are useful as genetic markers. Nucleic Acids Res 18: 6531-6535.

Wolfe AD, Xiang QY, Kepharts SR (1998). Assessing hybridization in natural populations of Penstemon (Scrophulariaceae) using hypervariable intersimple sequence repeat (ISSR) bands. Mol Ecol 7: 1107-1125. 